\title{
Corporate Social Disclosure during the Global Financial Crisis
}

\author{
Parvez Mia (Corresponding author) \\ Macquarie University, Australia \\ Tel: 88-018-1659-5846 E-mail: watch_399@yahoo.com
}

\author{
Abdullah- Al- Mamun \\ Multimedia University, 63100 Cyberjaya, Malaysia \\ Tel: 16-215-7752Ｅ-mail: mamun.freethinker@gmail.com
}

Received: June 8, 2011
doi:10.5539/ijef.v3n6p174
Accepted: July 22, 2011

Published: November 1, 2011

URL: http://dx.doi.org/10.5539/ ijef.v3n6p174

\begin{abstract}
The significant amount of research related to corporate social disclosure (CSD) over the last few decades indicates its importance. Prior studies have revealed continuous improvement in the level of CSD by corporations in different sectors. The recent economic and financial crisis has been identified by many economic and financial experts as the worst since the Second World War and is likely to have an impact on level of CSD. This study examines the extent of CSD before and during global financial crisis for 48 selected Australian companies. The results of the study reveal that there is an insignificant upward change in CSD during the financial crisis. In addition, this study examines the association between several firm level factors (profitability, leverage, change in profitability, change in leverage and size) and the extent of CSD and change in CSD. The study finds that the extent of CSD is not significantly associated with leverage and profitability but it is significantly associated with size. Additionally, change in profitability and size do not have any significant influence on change in CSD. However, change in leverage has a significant negative association with change in CSD.
\end{abstract}

Keywords: Corporate social disclosure, Global financial crisis.

\section{Introduction}

The purpose of this study is to investigate the extent of corporate social disclosure before (2006) and during (2008) global financial crisis (GFC) for 48 selected Australian utilities and industrial companies. Specifically, this study examines 1) the association between several firm level attributes (profitability, leverage and size) and extent of CSD; 2) the association between change in profitability, change in leverage, size and change in CSD. Corporate social disclosure addresses the social accountability of companies which may include but not limited to their product, human resources, community involvement, product safety, environmental impact of corporate operations, supplier and customer interactions (Gray et al.1987; Deegan and Rankin 1996; Smith et al. 2005). CSD focuses on broader audience (i.e., stakeholders) whereas corporate financial reports focus on a limited group of stakeholder, mainly investors and creditors (Smith et al., 2005).

"Reporting is necessity if companies are to know and understand their social and environmental impacts, and how to minimize the dangers and maximize the opportunities associated with new and emerging challenges" (KPMG 2008: 7). A number of prior studies related to CSD have focused on the finance and banking sector (Branco and Rodrigues, 2006) and the mining sector (Jenkins and Yakovleva, 2006), however, the utilities and industrial sector have not received much attention. This lack of attention to the utilities and industrial sector provides a motivation for this study. Previous studies relating to CSD were conducted during good economic times. Consequently, how firms react during the financial crisis in terms of providing social disclosure (SD) and more specifically, whether the extent of social disclosure (SD) increases or decreases during bad economic times compared to good economic times provides a further motivation for this study. Previous studies have provided conflicting evidence regarding the association between profitability and extent of CSD (Singh and Ahuja, 1983; Cowen et al 1987; Patten 1991). However, none of these studies have examined the association between a significant decline in profitability and the extent of CSD. This study selects companies whose profits declined significantly from 2007 to 2008, in order to examine the association between a significant decline in profitability and the extent of CSD. 
This study contributes to the literature by expanding discussions on corporate social disclosure in a new direction the extent of corporate social reporting / corporate social disclosure during a severe financial crisis. The findings of this study provide the general public, social investors, environment agencies, policy makers and regulators insights into attitudes regarding CSD during abnormal economic situations compared to normal economic situation. As far as is known, this is the first study to examine whether a change in CSD is associated with a change in profitability, change in leverage and / or size.

\section{Literature Review}

Evidence from developed and developing countries indicates that CSD is receiving increased attention by the various corporations and stakeholders. CSD is one of the means by which corporations can disclose how they are dealing with the social, environmental and economic issues (SustainAbility/UNEP 2002; KPMG 2008). Even though CSD is getting popular with companies, regulators, stakeholders group and academicians, not all companies are disclosing social information today. Some companies (e.g., Henkel, BHP, Johnson and Johnson) have norms in reporting non-financial information, others report only limited information, or in some cases, no information (Chen and Bouvain, 2009). CSD refers to the disclosure of information about companies' interactions with society. Corporate activities have an impact on employee related issues, community involvement, environmental concerns, other ethical issues and the corporation tries to reflect this aspect though CSD (Branco and Rodrigues, 2006). In other words, these activities can be described as corporate social responsibility (CSR) activities and CSD is the media of disclosing CSR activities.

Based on several prior findings, Gray et al., (1995a) argued that relation between CSD and profitability, size, industry type are not clear or consistent enough. They conclude with reference to two other studies (Gray et al., 1987; Guthrie and Parker, 1989, 1990) that SD is subject to time and country variance. Empirical studies indicate that SDs vary across companies, countries, industries, and time (e.g. Patten 1991; Gray et al. 1995b, 2001; Hackston \& Milne, 1996). Guthrie and Parker (1990) examined the annual reports of 150 companies in three countries; the U.S., U.K., and Australia and find that the level of CSD in Australia (56\%) is much lower compared to U.S (98\%) and U.K. (85\%). Over the last decade the extent of CSD has increased significantly in Australia and also other parts of the world (KPMG 2008) with the focus on CSR becoming broader. Haniffa and Cook (2005) suggest that the reason for this could be increases in legislation, risk, activities of pressure groups, ethical investors, specific events, awards, economic activities, media interest, societal awareness, and politics. Research related to corporate social disclosure started in Australia after 1980 with pioneering researchers (e.g., Guthrie and Mathews 1985; Guthrie and Parker 1989) conducting empirical studies on social reporting. Deegan and Gordon (1996) undertook a longitude study which revealed that the level of social reporting increased over time. Another study by Deegan et al.(2000) shows that sometimes companies report their social activities in response to an event or incident rather than the company's underlying responsibility to stakeholders. So, firms may react differently in disclosing their social information during the financial crisis period.

Previous studies related to factors influencing corporate social disclosure (CSD mainly consider a part of voluntary disclosure) identify several factors like size, profitability, listing status, industry, age, company profile, country, ownership structure etc (see Freedman and Jaggi 1988; Hackston and Milne, 1996; Gray et, al., 2001; Douglas et. al., 2004; Smith 2005; Bannany, 2007; Liu et al. 2009). The following section will focus on prior studies related to several determinants of CSD such as size, profitability, leverage and industry. This study excluded some factors such as listing status as in this study all the selected companies are listed; country has been excluded as all the companies are Australian; industry has been excluded as this study focuses on 2 types of industry sectors namely: utilities and industrial; company profile has been excluded as none of the selected companies are particularly visible to the public; and it is believed that there is no major change in company ownership structure. Therefore, ownership structure was excluded.

Prior studies revealed that bigger companies disclose more information than smaller ones (e.g., Cowen et al. 1987; Hackston and Milne 1996; Gray et, al. 2001; Patten 2002a; Bannany, 2007). Big companies also have greater pressure from various stakeholders, political parties and regulators (Brown \& Deegan, 1998) which may influence to disclose more information. Contrary to the findings of these studies Singh and Ahuja (1983), and $\mathrm{Ng}$ (1985) found no relationship between size and CSD. Profitable companies are assumed to disclose more voluntary information than those that are financially in trouble. Previous studies (e.g. Bowman, 1978; Patten, 1991; Mangos and Lewis, 1995) have theorized and found that profitable companies would be more likely to implement CSR disclosures. However, some researchers (e.g., Kelly, 1994 and Leuz, 1999) findings suggested a negative association between the extent of disclosure and profitability whereas others (e.g., Singh and Ahuja, 1983; Cowen et al., 1987; Freedman and Jaggi, 1988) suggested no association between profitability and CSD. So, association between profitability and CSD is inconclusive. In regard to the association between financial leverage and CSD Richardson and Welker (2001) 
found that companies with higher financial leverage have higher levels of SD. Furthermore, in terms of corporate voluntary disclosure it has been found that highly leveraged firms disclose more information (Salamon and Dhaliwal, 1980; Mitchell et al., 1995; Wallace et al., 1994). Patten (1991) study found that size and industry are significant explanatory variables for CSD when profitability is not. Patten (1991:300) mentions that "this study examines whether differences in profitability impact on the level of social information included in annual reports. The previous studies examined whether the level of SD impacted on profits". Cowen et. al (1987) find that size and industry are associated with SD but there is no significant association between SD and profitability.

\section{Theoretical Background}

Several theories are relevant in the area of CSD namely, stakeholder theory, legitimacy theory, proprietary cost theory, among other theories. The distinction among these theories is often unclear and it appears that there is a great deal of overlap because all the theories are concerned with the interplay between the corporations and its stakeholders (Gray, et.al 1995a; O’Donovan, 2002). The main difference between them appears to be the viewpoint from which they are observed and tested (O’Donovan, 2002).

\subsection{Stakeholder Theory}

Stakeholder theory assumes that an organization's management is expected to take on activities by those identifiable groups or individuals who can affect and who are affected by the achievement of an organization's objectives (Boesso and Kumar, 2007). A number of empirical studies have utilized stakeholder theory as their theoretical framework in the area of voluntary disclosure more specifically in the area of CSD (e.g., Smith et al., 2005). This theory presumes that the corporation has responsibility not only to managers, shareholders and creditors but also to customers, suppliers, communities and the general public. These stakeholders are important for a corporation's survival and success. As such dialogue is necessary between firm management and its stakeholders (Smith et al., 2005). CSD can be a way of communicating with those stakeholders (Gray et al., 1995a).

\subsection{Legitimacy Theory}

Corporations that can't fulfil societal expectations with regard to social responsibility may lose their legitimacy that will threaten their survival (Douglas et al., 2004). "Legitimacy theory is based on the idea that in order to continue operating successfully, corporations must act within the bounds of what society identifies as socially acceptable behaviour (O'Donovan, 2002: 344). Unlike stakeholder theory, legitimacy theory has been used by prior studies (e.g., Patten, 1991; O’Donovan, 2002; Nazli Ahmed et al., 2003; Haniffa and Cooke, 2005). Businesses are responsible for their operations and the impact of these operations on the wider stakeholders. This sentiment is clear from Tinker and Niemark's (1984: 84) statement that “...the public, in general, became increasingly aware of the adverse consequences of corporate growth. They pressured both business and government to make outlays to repair or prevent damage to the physical environment, to ensure health and safety of consumers, employees, and those who reside in the communities where products are manufactured and wastes are dumped, and to be responsible for the consequences of technological unemployment and plant closings". For example, businesses (e.g. BP oil spill in 2010) are forced to take responsibility for various social issues when those occurred as the consequence of their activities. O'Donovan (2002) study showed support for legitimacy theory as an explanatory factor for environmental disclosures. Nazli Ahmad et al (2003: 8) explain "if companies are aware of the changes in public perception and awareness of the need for businesses to be socially responsible, companies will attempt to seek legitimacy. In other words, companies will respond to the increased awareness by increasing their CSR disclosures in annual reports"

\subsection{Proprietary Cost Theory}

According to proprietary theory, companies reduce the level of information because of two types of costs namely preparation and competitive costs. When proprietary costs are high, companies move from full to partial disclosure (Wagenhofer, 1990). Voluntary disclosures help firms to reduce information asymmetry and the cost of capital (Grossman, 1981; Milgrom, 1981). However, companies limit voluntary disclosure when there is some proprietary cost associated with it (Prencipe, 2004). Sometimes companies may disclose more social information to distract various stakeholder groups from their bad economic performance and vulnerability especially during bad economic time.

\subsection{Corporate Social Disclosure and Economic Downturn}

Corporate social responsibility (CSR) and its disclosure is one of the most discussed topics among recent accounting researchers. A number of researchers have found that over time (Haniffa and Cook (2005): 1996 to 2002; Gray et al. (1995a): 1979 to 1991) CSR activities and its disclosures (CSD) are continuously increasing. Previous studies have been taken during the periods of stable economic circumstances. The world didn't see any severe economic crisis over the last few decades especially when companies try to increase their focus on broader group of stakeholder and 
start making more and more CSD. The business world has now seen the worst part of their business period. The current global financial crisis is believed to be different from previous financial crisis (Souto, 2009; Goldin and Vogel, 2010). Souto (2009) argues that the current economic and financial crisis as agreed by many economic and financial experts is the worst since the Second World War. Highly successful companies with the most developed institutional governance (e.g. Washington Mutual and Lehman Brothers Holdings Inc) declared bankruptcy in September, 2008, due to the ongoing financial crisis. These and other high profile corporate failures indicate that the impact of corporation activities not only affect the groups with direct financial interest in the corporation but also affect other stakeholders like employees, customers, suppliers and society as a whole (Smith et al, 2005). Karaibrahimoglu (2010:382) states that "organizations have a large, positive or negative, direct or indirect influence on every party in society". In addition, corporate activities can have a significant impact on the environment. CSD disclose corporations' contribution for the society's well being and what the adverse effects of their business activities are. CSD can be considered as a sub-set of corporate disclosure. It is costly to produce and disclose CSR activities but based on previous studies it seems that CSD is increasing which indicates that cost is not a problem in reporting SD.

According to legitimacy and stakeholder theories companies need to disclose information to legitimise their business activities and fulfil various stakeholders' demands for information irrespective of good or bad economic circumstances. In particular, business activities affect society as a whole irrespective of bad or good economic circumstances and they cannot simply ignore their stakeholders and their liability to stakeholder during bad economic circumstances. Consequently it seems that companies are morally accountable to disclose social information. Legitimacy and stakeholder theories support disclosure of social information irrespective of economic circumstances. Companies may try to disclose more information when facing difficult economic circumstances as providing more SD can help to rebuild and/or increase corporate image which can increase the acceptance of companies' existence in the society (Branco and Rodrigues, 2006).

\section{Hypothesis Development}

\subsection{Financial Crisis}

Proprietary cost theory (discussed above) suggests that firms limit their voluntary disclosure level because of two costs namely, preparation costs and competitive costs (Prencipe, 2004). Recent GFC was regarded as the worst the world has encountered, leaving the most developed institutions in difficulty (Goldin and Vogel, 2010), and firms might have reduced their voluntary disclosure because they may not be able to afford the preparation costs as is suggested by proprietary cost theory. A prior study (Mohd Ghazali and Weetman, 2006) in the area of voluntary disclosure conducted in Malaysia following the 1997 Asian financial crisis provided evidence that despite the disorder of the economic crisis, the financial crisis at the time did not have a major impact on voluntary disclosure. A recent study by Rowe, A. (2010) indicates that the level of SD did not decrease during the GFC. Rowe, A. (2010) also cited SIRAN commissioned report - S\&P 100 sustainable Reporting Comparison - shows more companies are issuing GRI reports (a social performance indicator used to measure the level of CSD). In fact the extent of disclosure increased during this time. During crisis periods investors are more concerned about the company's performance. SD can be used to minimise that concern. Given the scenario of events in the chosen time periods (2006 to 2008) following hypothesis is developed and stated in the null form:

$H_{1}$ : There is no difference between the extent of corporate social disclosure (CSD) of selected Australian companies before and during the recent financial crisis.

\subsection{Profitability}

The GFC appears to have had a significant impact on companies' profitability. Profitable companies are more visible to the public and their activities easily come to people's attention. Profitable companies disclose social information to legitimise their existence by demonstrating their contribution to society's well being (Haniffa and Cooke, 2005). Patten (1991) argues that it is public pressure which influences the extent of CSD not profitability. It can be argued that during a financial crisis when companies' profitability declines, it is more difficult for companies to produce extra disclosure not required by law. However, providing more disclosure can provide the opportunity for companies to tell some good stories and the benefits of this extra disclosure can surpass the cost of producing it. Moreover, a drop in profitability during economic crisis period may create problems for companies in attracting investors. Such companies may disclose more information to make their position stronger within society. Companies will try not to minimise the extent of their SD as it can give a negative sign about the companies' vulnerability. Based on the literature review related to profitability and SD, it appears that profitability does have a significant influence on the extent of CSD but whether this influence or association is positive or negative is not clear. If 
profitability has any influence on the extent of CSD, then it can be assumed that the extent of disclosure may change with change in profitability. Based on the forgoing discussion the following hypotheses are formulated:

$H_{2 a}$ : There is no association between the extent of CSD and profitability.

$H_{2 b}$ : There is no association between change in CSD and the change in profitability.

\subsection{Leverage}

Very high leverage can put companies in a risky position, consequently when leverage increases companies are normally under pressure from creditors or banks. Often companies need to maintain a certain leverage (debt-equity) ratio. If leverage gets to high, chances are companies will be highly monitored by stakeholders especially by the banks, creditors and investors. Therefore, companies are likely to disclose more information to the public and those stakeholders to assure them that they are not breaching any debt-covenant conditions. Prior studies find that companies with higher leverage disclose more voluntary social and financial information (Malone et al 1993; Giner et al., 1997; Richardson and Welker, 2001). It is possible companies that have financial problems during a financial crisis are likely to borrow more which will increase the level of firm leverage. Additionally they might also delay paying interest during the financial crisis period which can also increase their leverage. As a result, it is likely that these companies will have higher leverage during the GFC. One of the major reasons for Lehman Brothers' liquidation was very high leverage. Lehman Brothers, for example, in its last annual financial statements, showed accounting leverage of 30.7 times ( $\$ 691$ billion in assets divided by $\$ 22$ billion in stockholders' equity).(Note 1) If, as indicated earlier, leverage has a positive influence on SD, then a positive change (increase) in leverage will have a positive influence on SD. Based on this discussion and literature review the following hypotheses are formulated:

$H_{3 a}:$ There is no association between the extent of CSD and leverage.

$H_{3 b}$ : There is no association between the change in CSD and change in leverage.

\subsection{Firm Size}

Large companies have greater capability and capacity to disclose more information in every area. Large companies, to improve their image in society and hence legitimise their existence, might be more interested than small ones in fulfilling social norms, belief, values and definition by disclosing some information about their social activities in their annual reports (Bannany 2007). Big companies are also politically more visible which can influence them to provide more SD (Zeghal and Ahmed 1990). As big companies have more responsibility to the society and wider group of stakeholders and they are more likely try to follow social values to legitimise their existence, big companies will provide more disclosure. If size has a significant influence on CSD, it is also possible that there will be greater change in CSD for the larger companies than smaller companies. Based on above discussion and literature review the following hypotheses are developed;

$H_{4 a}:$ There is no association between extent of CSD and firm size.

$H_{4 b}$ : There is no association between change in CSD and firm size

\section{Research Methodology}

Two regression models are used to test hypotheses $2 \mathrm{a}, 2 \mathrm{~b}, 3 \mathrm{a}, 3 \mathrm{~b}, 4 \mathrm{a}$ and $4 \mathrm{~b}$. For this study CSD is the dependent variable which is similar to almost all other previous studies. These models also include 5 independent variables: profitability (ROE), change in profitability $(\triangle \mathrm{ROE})$, leverage (LEV), change in leverage $(\triangle \mathrm{LEV})$ and firm size (REV) which have been taken from aspects of financial analysis database. The following regression models are formulated:

Model 1: $\quad$ SDI $06=\infty+\beta 1$ ROE $06+-\beta 2$ LEV $06+\beta 3$ REV $06+\varepsilon$

Model 2: $\quad \Delta \mathrm{SDI}=\infty+\beta 1 \Delta \mathrm{ROE}-\beta 2 \Delta \mathrm{LEV}+\beta 3 \mathrm{REV} 06+\varepsilon$

Where,

SDI $06=$ Extent of Corporate Social Disclosure in Year 2006

$\Delta$ SDI $=$ Corporate Social Disclosure Change from 2006 to 2008

$\mathrm{ROE}=$ Return on Equity (proxy for profitability)

$\Delta \mathrm{ROE}=$ Change of ROE (ROE $2008-\mathrm{ROE} 2006$, proxy for change in profitability)

Lev $=$ Leverage, where Int. Bearing Liability / Net Assets

$\Delta \operatorname{LEV}(08-06)=$ Change of Lev $(\operatorname{Lev} 2008-\operatorname{Lev} 2006)$ 
$\operatorname{Rev}=\log$ of Total Revenue (proxy for size)

$\varepsilon=$ Error

\subsection{Development of Disclosure Checklist}

One important requirement in analysing the content of company annual reports is to develop an appropriate disclosure checklist. The GRI checklist has been widely used in a number of sustainability surveys and to measure the level of SD (e.g., PricewaterhouseCoopers 2002, Sustainability/UNEP 2002; KPMG 1997, 2008; Rowe, 2010). Selected sample companies for all those studies were big companies which make GRI more applicable. But the selected companies for this study are much smaller compared to top 100 Australian companies. Therefore, using the GRI may not be appropriate in measuring the extent of SD for these companies. Consequently, the SD checklist developed (Table 13) for this study was adapted from the checklist developed by Gray et. al (1995a), Haniffa and Cook (2005) and Smith et al (2005) with some modification to make it suitable for the selected Australian companies. This checklist would appear to be appropriate for Australia as a similar checklist has been developed and used to detect or identify the extent of CSDs in U.K., U.S. and European firms. As Haniffa and Hudaib (2007) pointed out, one of the most important things in dealing with content analysis is the selection and development of categories into which content units can be classified. Consequently, the 33 items included in the disclosure checklist are classified into 5 broad categories such as: community involvement, environmental, human resources, product and customer related issues.

\subsection{Scoring Disclosure Items}

The SD checklist needs to be scored to measure the extent of CSD. The extent of CSD can be measured by using both weighted and unweighted scores. While unweighted indices score each item equally, the weighted approach assigns a weight to the single items in order to allow for the different relevance of each of them (Prencipe, 2004). Empirical studies that make use of only un-weighted indices include (e.g., Chau and Gray, 2002; Haniffa and Cooke, 2002; Mohd Ghazali and Weetman, 2006). An unweighed scoring index is used for this study. In other words, if the item in the checklist is disclosed in the annual report it is scored as 1 and 0 otherwise. There are 33 items in the checklist and if any selected company disclosed 7 items, then the total score for that particular company would be 7 .

\subsection{Research Instrument}

Many prior studies have used content analysis in the area of voluntary and social disclosure and established the annual report as the major CSR communication medium to various stakeholders (e.g.Guthrie and Parker, 1990; Gray et al., 1995a; Gray et al., 1995b; Deegan and Gordon, 1996; Belal, 2001; Branco and Rodrigues, 2006; Mohd Ghazali and Weetman, 2006). Consistent with prior studies this study also analyses the content of company annual reports. To appreciate CSR disclosure better, annual reports are considered suitable documents for analysis. The annual report is a widespread and popular means of communication to stakeholders and it has high credibility (Singh and Ahuja, 1983; Guthrie and Parker, 1990; Tilt 1994; Gray et al., 1995a, 1995b; Adams, 2004; Raman, 2006). For most of the selected companies for this study, annual reports are assumed to be the primary source of communication. Annual reports are used by a number of stakeholders as the sole source of certain information (Deegan and Rankin, 1996). Moreover, none of the selected companies produces any separate CSR disclosure. Furthermore, as this study focuses on CSR reporting in 2006 and 2008, it may not be able to extract data from companies from their website for those 2 years. It could be virtually impossible to collect all corporate communications relating to social matters over a long period of time, resulting in incomplete data and inconsistent content analysis. (Gray et. al., 1995b). Some other benefits of the use of annual report is that it is a legal requirement and produced every year, therefore it is easy to compare (Tilt, 2001) between one year report with another year report. Annual reports are also more accessible for research purposes (Woodward, 1998) as they are publicly available.

Content analysis is used to measure the level of information disclosed by selected companies in relation to the social and environmental aspects. Abbott and Monsen (1979:504) define content analysis as, "a technique for gathering data that consists of codifying qualitative information in anecdotal and literary form, into categories in order to derive quantitative scales of varying levels of complexity". Additionally, content analysis has been described as "a research technique for making replicable and valid inferences from data according to their context" (Krippendorf, 1980). Detecting or identifying the existence or nonexistence of social information is one of the simplest forms of content analysis (Patten, 2002b; Purushothaman et al., 2000). One of the principle drawbacks of this approach is that it does not allow the researcher to measure number of lines and depth of information disclosed. The number of different topics discussed in an annual report can be taken as a reasonable measure of management's eagerness to provide socially responsible information in general (Bewley and Li, 2000: 206). 


\subsection{Sample Selection and Data Description}

As this study is based on a time line of before and during the recent GFC, 2006 is used to represent before the current financial crisis while 2008 is used to represent a year in the middle of financial crisis time. The sample for this study consists of 48 utilities and industrial companies listed on the ASX. These 48 companies were selected based on their significant profitability drop from 2007 to 2008. Annual reports and other data for the sample companies were collected from 'Aspect Annual Report Online' and 'Aspect Fin Analysis' Database. All companies in the sample were listed on Australian Stock Exchange (ASX) in 2006, 2007 and 2008.

\section{Data Analysis}

Table 1 presents the descriptive statistics for the dependent variables for 48 sample companies used in the study. The mean of ROE is negative 0.250 which means on average sample companies made a loss during 2006. Companies' profitability during that year ranges from negative $58.70 \%$ to positive $43.30 \%$. Average profitability decreased $66.20 \%$ from 2006 to 2008 period. This result indicates that companies included in the sample experienced a substantial profitability drop during the GFC. In 2006 the leverage for sample companies ranged from -0.584 to +5.017 with a median of 0.127 and a mean of 0.491 , which indicates a relatively moderate leverage for sample firms. The mean of 0.41 for change in leverage from 2006 to 2008 indicates that during the GFC the average leverage of sample companies increased by $41 \%$. An increase in leverage could be either the result of increases in interest bearing loans or a reduction of net assets during the GFC. A natural log transformation of firm size is adopted in order to avoid any heteroskedasticity and non-linearity problems that could be introduced by using raw firm size data. The average natural log size of the sample is 6.953 ranging from 3.524 to 9.144 .

Table 2 presents the descriptive statistics for the dependent variables which show that average number of items disclosed by each selected companies in year 2006 is 3.021 which is relatively low. The extent of disclosure ranges from 0 to 9 with a standard deviation of 2.037 and median of 2.5. The $\Delta$ CSD mean is 0.063 , which indicates that CSD has changed from 2006 to 2008 and this change is positive (increased/upward) change. The range of this change is from -3 to 3. Standard deviation for $\triangle \mathrm{CSD}$ is much higher (1.590) than its mean (0.063), which tells that $\triangle \mathrm{CSD}$ for some companies, is much higher than others.

\subsection{Correlation Analysis}

For this study, Pearson product moment correlation coefficients (r) are computed to examine the correlation between the independent variables. Correlation matrix of the independent variables is shown in table 4 and 5. Table 4 shows that in 2006, profitability is negatively correlated with leverage as expected and positively correlated with size. Table 4 also indicates that leverage and size are not correlated.

Table 5 indicates that change in profitability is negatively correlated with change in leverage at $1 \%$ significance level, which indicates that if profitability decreases, leverage will increase. However, leverage is not significantly correlated with size. Both tables show that some variables are correlated which is a concern for multicollinearity. However, multicollinearity is not a problem when correlations between independent variables are lower than 0.90 (Kaplan 1982) and 0.80 (Emory, 1982; Gujarati, 1995). So, it appears that the magnitude of the correlations between independent variables did not create severe multicollinearity problems.

\subsection{Result of Content Analysis (Hypothesis 1)}

This section outlines the results related to Hypothesis 1 . Content analysis and descriptive statistics were used to measure the extent and change in CSD during the GFC compared to before the GFC. The maximum possible number of items that can be disclosed by all the companies are 1584 (33 items by each company X 48 companies). The forty eight selected companies provided 145 SD items in 2006 and 148 SD items in 2008.

Table 3 shows the extent of SD in 2006 is $9.15 \%$ (145/1584) and 9.34\% (148/1584) in 2008, which indicates a very slight change in CSD (only $0.19 \%$ increase) over the period. The overall mean change is 0.063 items, which is not significant. Table 3 and results reported in section descriptive statistic do not support $\mathrm{H} 1$ as insignificant difference is found between the extent of CSD for selected Australian companies before (2006) and during the GFC (2008). Table 3 also presents the outcome of the content analysis of annual reports and descriptive statistics for selected companies including paired t-test. This table also summarises the total disclosure made by all the selected companies under each category. Table 3 reveals that the amount of SD is comparatively small and its mean varies from a low of 0.125 for Customer Disclosure to a high of 1.521 for Environmental Disclosure in 2008.

\subsection{Extent of Corporate Social Disclosure by Each Category:}

The results in Table 3 shows that the 48 companies together provide only 6 community related items, which is $4.04 \%$ of total disclosure items in 2008 , and $4.05 \%$ in 2006 . However, there is no change in the number of items disclosed 
by all the companies from 2006 to 2008 . There are 64 items (table 3) disclosed in 2006 and 74 items in 2008 by all companies under the environmental category. In terms of numbers, this category has the highest increment of SD items over the years. The overall increase is $14.06 \%$ or 9 items from 2006 to 2008 . However, there is no statistically significant change $(\mathrm{t}=1.42 ; \mathrm{p}=0.162)$ for the number of items disclosed under this category during and before the GFC. Overall the extent of disclosure under the environment category is higher than the other four categories. This result is consistent with Ernst and Ernst (1978), Zeghal and Ahmed (1990). 9 items were disclosed in 2006 and 16 items in 2008 under the human resources category. The overall increase is $77.78 \%$ or 7 items from 2006 to 2008 which is significant at $10 \%$ level. There is no significant change for number of items disclosed under the customers' category during the GFC compared to before the GFC. In 2006 all companies together provided 14 disclosure items whereas 15 items were disclosed in 2008. Table 3 indicates that the movement in product or service related disclosure from 2006 to 2008 is very different from all other previous types of disclosure categories. Unlike other categories of disclosure, there is a significant decrease in the number of disclosure items from 52 (2006) to 38 (2008). This is the only category that has a decreasing rate of disclosure which is significant at $5 \%$ level $(t=-2.19$ and $\mathrm{p}=0.033$ ).

\subsection{Overview of Extent of Corporate Social Disclosure Findings:}

Overall there is $0.19 \%$ change for the level of disclosure from 2006 to 2008 which is not significant. One possible reason could be cost. It is costly to produce SD as argued by Brammer and Pavelinn (2004). However, there is a significant positive change in the extent of CSD in the human resource category and significant negative change in product category from 2006 to 2008. There is positive change for environmental related disclosure; however this change is not significant. Overall it appears that corporations have tended to increase the level of SD which is similar with prior longitudinal studies (Guthrie 1989; Gray et al 2001; Haniffa and Cooke 2005). The number of companies disclosing social information also appears to have increased. Two categories of SD (environment and HR) increased over the two years (from 2006 to 2008). A significant increase in HR related disclosure indicates that corporations are more concerned about their employees particularly the employees' health and workplace safety.

\subsection{Results of Regression Analysis}

Two regression models are used in this study. Model 1 is used to test H2a, H3a and H4a null hypotheses. Table 6 provides the regression results for model 1 which has R-Sq $24.6 \%$ and explains 19.40\% (adjusted R-Sq) of the relationship between the level of SD and the independent variables and indicates that the model is reasonably well specified and has good explanatory power. This model is significant at $1 \%$ level $(\mathrm{P}=0.006)$. It is hypothesized that the extent of CSD is influenced by profitability however the direction of this association is unknown as the results of prior studies are mixed. Regression result reveals that the coefficient for profitability is positive $(\beta=0.005)$ but not significant $(\mathrm{p}=0.989)$, indicating that extent of CSD is not significantly associated with the level of profitability. Therefore, H2a is not supported. However, it is consistent with prior studies for example, Singh and Ahuja, (1983) and Cowen et. al (1987) but inconsistent with Patten (1991) and Haniffa \& Cooke (2005). The coefficient for leverage is -0.072 with a p-value of 0.857 . Similarly this result indicates that there is no association between the extent of CSD and leverage and it does not support hypothesis 3a. This result is consistent with prior studies (Kelly, 1994 and Leuz, 1999) but is inconsistent with other prior studies, for example, Mitchell et al., 1995; Giner et al., 1997; Haniffa and Cooke 2005. The regression results indicate a positive relationship between size $(\beta=0.755 ; \mathrm{P}=$ 0.003 ) and extent of CSD at the $1 \%$ significance level. This result supports H4a, supporting the proposition that there is a positive association between firm size and the extent of CSD. In other words, larger firms provide more CSD. This result is similar to result of studies undertaken by Gray et al 1995; Doglus et al 2004; Bannany 2007.

Model 2 is used to test Hypotheses $2 \mathrm{~b}, 3 \mathrm{~b}$ and $4 \mathrm{~b}$. Table 7 presents the regression results for model 2 ( $\triangle \mathrm{CSD}$ from 2006 to 2008) showing an R-Sq 9.3\% and adjusted R-Sq 3.20\% which indicates that this model explains only $3.2 \%$ of the relationship between the change in CSD and the independent variables. It is hypothesised that $\triangle \mathrm{ROE}$ (profitability) and $\triangle \mathrm{LEV}$ would be associated with the change in CSD but the results of the regression model indicates that there is no significant association between change in profitability $(\beta=-0.123 ; \mathrm{P}=0.368)$ and $\Delta \mathrm{CSD}$, suggesting that even though company profitability declined during the GFC, this had no effect on the change in CSD. This result does not support hypothesis $2 \mathrm{~b}$. This finding is not surprising since the results of model 1 indicate that there is no association between profitability and CSD. However, the results do indicate that change in leverage is negatively associated with change in CSD at $10 \%$ significance level $(\beta=-0.310 ; \mathrm{P}=0.052)$, which is contrary to hypothesis $3 \mathrm{~b}$. This finding indicates that firms that have a significant increase in leverage result in a decrease in the amount of CSD. This result is contrary to agency theory which suggests that firms need to maintain their debt covenants to reach equilibrium when leverage gets high with firms providing more information to reduce the information gap. As a result firms disclose more information when leverage is high in order to assure their creditors that they are not breaching any debt covenants (Schipper, 1981). Finally firm size has coefficient 0.046 with a 
p-value of 0.789 indicating that firm size is not significantly associated with change in CSD. This result does not support hypothesis $4 \mathrm{~b}$.

The descriptive statistics (table 3) confirms that there is upward trend in CSD. This change could be the result of a tendency for companies to increase their CSD over time (Gray et al 1995). It could also be the result of legislative and/or regulatory change or a response to public concern, pressure from various environmental groups (Deegan and Gordon 1996), media (Haddock-Fraser and Fraser 2007) ethical considerations (KPMG 2008) which have influenced firms to increase their CSD.

\section{Conclusion and Implications}

This study moves beyond the limits of choosing top ASX and highly environmental sensitive companies and measures the extent of SD for those companies having problems with profitability during GFC. This study reveals that in line with prior studies (Gray et al, 2001; Haniffa and Cooke, 2005), CSD have been increasing for selected companies over time. Even though the sample companies are not highly visible or environmentally sensitive, the study reveals that most of the sample companies provide at least one type of SD item in their annual reports. Most of the disclosed items are related to the environment (44.14\% of total disclosed items in 2006 and $73 \%$ of total disclosed items in 2008) and human resources (52\% of total disclosed items in year 2006 and 38\% in year 2008). The findings show that the extents of CSD for selected companies are very low in both years. There are several costs companies need to bear if they want to provide social information in their annual reports; such costs include measuring and verifying social impacts, as well as the administrative burden of collecting and publishing such information (Verrecchia 1983, Cormier \& Magnan 1999). Extent of these SDs is only significantly associated with firm size. There are some upward changes in overall SD from 2006 to 2008 but size or change in profitability is not associated with the upward changes. However, this study shows that change in CSD is negatively associated with change in leverage during the study period. This study shows insignificant increase in CSD during GFC compared to before GFC. However, as far as selected utilities and industrialised sector companies are concerned, SDs tend to represent a relatively minor quantity of disclosure when compared with corporate financial disclosures.

The findings of the study provide evidence that utilities and industrial firms are not avoiding SD in their annual reports during financial crisis, rather the amount of disclosure increased during the GFC compared to before the GFC. However, the extent of CSD still remains very low. Corporations have disclosed information regarding how they deal with GFC, in terms of whether the GFC had any adverse impact on these companies or whether company strategy or objectives have changed in regards to social activities. Government and regulators can encourage and provide a framework for the companies to provide more information to the public during unfavourable economic periods as many companies might have suffered from it. More social information can make stakeholders well aware of the corporations' social activities during economic crises. The study also found that there is an insignificant change in CSD from 2006 to 2008. Consequently it is difficult to conclude whether the GFC has any influence on change in CSD. It could be the norm (KPMG 2008) to disclose more information in more recent years compared to prior years. It would appear that companies provide more CSD as time goes by (Gray et al., 1995). During the GFC, company's social activities decrease (Karaibrahimoglu, 2010) but the extent of CSD increases is insignificant.

This study has several limitations that must be acknowledged. The sample size of this study is low (48 companies) and only 2 types of industry sectors are taken into consideration. As a result generalisation of the findings of this study for other sectors should be done with caution. Future research can be undertaken using a larger sample to include a greater number of industry sectors. Future research could also investigate the impact of the GFC in different countries where the impact of GFC was more severe than in Australia such as the U.S.A.

\section{References}

Abbott, W.F. and Monsen, R.J. (1979). On the measurement of corporate social responsibility: self-reported disclosures as a method of measuring corporate social involvement, Academy of Management Journal, Vol. 22 No. 3, pp. 501-15. http://dx.doi.org/10.2307/255740

Adams, C.A. (2004). The ethical, social and environmental reporting performance portrayal gap, Accounting, Auditing and Accountability Journal, Vol. 17, No. 5, pp. 731-757. http://dx.doi.org/10.1108/09513570410567791

Bannany, M. (2007). A study of determinants of social disclosure level in UK banks, Corporate Ownership and Control, Vol. 5, Issue 1.

Belal, A.R. (2001). A study of corporate social disclosures in Bangladesh, Managerial Auditing Journal, Vol. 16, pp. 274-289. http://dx.doi.org/10.1108/02686900110392922

Bewley, K. and Li, Y. (2000). Disclosure of environmental information by Canadian manufacturing companies: a voluntary disclosure perspective, Advances in Environmental Accounting and Management, No. 1, pp. 201-226. 
Boesso, G. and Kumar, K. (2007). Drivers of Corporate Voluntary Disclosure. Accounting, Auditing \& Accountability Journal, Vol. 20 No. 2, pp. 269-296. http://dx.doi.org/10.1108/09513570710741028

Bowman, E.H.(1978). Strategy, Annual Reports, and Alchemy. California Management Review, Vol. 20 No. 3, pp. 64-71.

Brammer, S. and Pavelinn, S. (2004). Voluntary social disclosures by large UK companies, Business Ethics: A European Review, Vol. 113 No. 2/3.

Branco M, C. and Rodrigues L, L (2006). Communication of corporate social responsibility by Portuguese banks A legitimacy theory perspective, Corporate Communications: An International Journal, Vol. 11 No. 3, pp. 232-248.

Brown, N. and Deegan, C. (1998). The public disclosure of environmental performance information-dual test of media agenda setting theory and legitimacy theory, Accounting and Business Research, Vol 29 No. 1, pp. 21-41.

Chau, G.K. and Gray, S.J. (2002). Ownership Structure and Corporate Voluntary Disclosure in Hong Kong and

Singapore. The International Journal of Accounting, Vol 37, pp. 247-65. http://dx.doi.org/10.1016/S0020-7063(02)00153-X

Chen, S. and Bouvain, P. (2009). Is Corporate Responsibility Converging? A Comparison of Corporate Responsibility Reporting in the USA, UK, Australia, and Germany, Journal of Business Ethics, Vol 87, pp. 299-317. http://dx.doi.org/10.1007/s10551-008-9794-0

Cormier, D. and Magnan, M. (1999). Corporate environmental disclosure strategies: determinants, costs and benefits, Journal of Accounting, Auditing and Finance, Vol. 14 No. 4, pp. 429-451.

Cowen, S.S., Ferreri, L.B. and Parker, L.D. (1987). The impact of corporate characteristics on social responsibility disclosure: a typology and frequency-based analysis, Accounting, Organizations \& Society, Vol. 12 No. 2, pp.111-122. http://dx.doi.org/10.1016/0361-3682(87)90001-8

Deegan, C. and B. Gordon (1996). A Study of Environmental Disclosure Practices of Australian Corporations, Accounting and Business Research, Vol. 26, No. 3, pp. 187-99.

Deegan, C., and M. Rankin. (1996). Do Australian Companies Report Environmental News Objectively? An Analysis of Environmental Disclosures by Firms Prosecuted Successfully by the Environmental Protection Authority, Accounting, Auditing and Accountability, Vol. 9 No.2 pp. 50-67. http://dx.doi.org/10.1108/09513579610116358

Deegan, C., Rankin, M., Voght, P. (2000). Firms' disclosure reactions to major social incidents: Australian evidence, Accounting Forum, Vol. 24 No.1, pp.101-30. http://dx.doi.org/10.1111/1467-6303.00031

Douglas, A. Doris, J. and Johnson, B (2004). Corporate social reporting in Irish financial institutions. The TQM Magazine, Vol.16 No.6, pp. 387-395. http://dx.doi.org/10.1108/09544780410563301

Emory, E. (1982). Business Research Methods. Homewood, IL: Irwin.

Ernst and Ernst(1978).Social Responsibility Disclosures: Surveys for Fortune 500 Annual Reports, Cleveland, Ohio

Freedman, M. and Jaggi, B. (1988). An Analysis of the Association Between Pollution Disclosure and Economic Performance, Accounting, Auditing and Accountability Journal, Vol. 1, No. 2, pp. 43-5. http://dx.doi.org/10.1108/EUM0000000004623

Giner, B., Ruiz, A., Cervera, N. and Arce, M. (1997). Accounting policy choice and the disclosure of segmental information: Spanish evidence, Paper presented at the 20th EAA Annual Congress, Graz, April.

Goldin, I., and Vogel, T. (2010). Global Governance and Systemic Risk in the 21st Century: Lessons from the Financial Crisis, Global Policy, Vol 1 No.1, pp 4-15. http://dx.doi.org/10.1111/j.1758-5899.2009.00011.x

Gray, R., Owen, D. and Maunders, K.(1987). Corporate Social Reporting, Prentice-Hall, Englewood Cliffs, NJ.

Gray, R., Kouhy, R., Lavers, S. (1995a). Corporate social and environmental reporting: A review of the literature and a longitudinal study of UK disclosure, Accounting, Auditing and Accountability Journal, Vol 8, No 2, pp. 47-77. http://dx.doi.org/10.1108/09513579510146996

Gray, R., Kouhy, R., Lavers, S. (1995b). Methodological themes, constructing a research database of social and environmental reporting by UK companies, Accounting, Auditing \& Accountability Journal, Vol 8 No. 2, pp. 78-101. http://dx.doi.org/10.1108/09513579510086812

Gray, R., Javad, M., Power, D.M., Sinclair, C.D. (2001). Social and environmental disclosure and corporate characteristics: A research note and extensio, Journal of Business Finance \& Accounting, Vol 28 No.3/4, pp. 327-356. http://dx.doi.org/10.1111/1468-5957.00376 
Grossman, S. (1981). The role of warranties and private disclosure about product extent, Journal of Law and Economics, Vol 24, No 3, pp. 461-483. http://dx.doi.org/10.1086/466995

Gujarati, D. (1995). Basic Econometrics. McGraw Hill, NY.

Guthrie, J.E., Mathews, M.R. (1985). Corporate social accounting in Australasia, in Preston, L.E. (Eds).Corporate Social Performance and Policy, JAI, New York, NY, .

Guthrie, J. and Parker, L.D. (1989). Corporate social reporting: A rebuttal of legitimacy theory, Accounting and Business Research, Vol: 19 No.76, pp. 343-352.

Guthrie, J. and Parker, L.D. (1990). Corporate Social Disclosure Practice: A Comparative International Analysis, Advances in Public Interest Accounting, Vol. 3, pp. 159-76.

Hackston, D., Milne, M.J. (1996). "Some determinants of social and environmental disclosures in New Zealand companies", Accounting, Auditing \& Accountability Journal, Vol. 9 No.1, pp.77-108. http://dx.doi.org/10.1108/09513579610109987

Haniffa, R.M. and Cooke, T.E. (2002). Culture, Corporate Governance, and Disclosure in Malaysian Corporations, ABACUS, Vol 38 No. 3, pp. 317-349. http://dx.doi.org/10.1111/1467-6281.00112

Haniffa, R.M. and Cooke, T.E (2005). The Impact of Culture and Governance on Corporate Social Reporting, Journal of Accounting and Public Policy, Vol 24, pp. 391-430.

Jenkins, H., and Yakovleva. N. (2006). Corporate Social Responsibility in the Mining Industry: Exploring Trend in Social and Environmental Disclosure, Journal of Cleaner Production, Vol 14, No 3-4, pp. 271-284.

Kaplan, R. (1982). Advanced Management Accounting. Englewood Cliffs, NJ: Prentice-Hall

Karaibrahimoglu, Y. Z (2010). Corporate Social Responsibility in Times of Financial Crisis, African Journal of Business Management, Vol. 4 No.4, pp. 382-389,

Kelly, G. J. (1994). Unregulated Segment Reporting: Australian evidence, British Accounting Review, Vol 26, pp. 217-234.

KPMG (1997). Survey of Environmental Reporting 1997 (London: KPMG). Lehman, C. (1992). Accounting's Changing Roles in Social Conflict (Paul Chapman).

KPMG. (2008). KPMG International Survey of Corporate Responsibility Reporting 2008, Amsterdam, The Netherlands. Krippendorf, K. 1980. Content Analysis: An Introduction to Its Methodology. Beverly Hills,

Krippendorf, K.(1980). Content analysis: An introduction to its methodology, Sage Publications,Newbury Park, CA. Liu, X and Anbumozhi, V. (2009). Determinant factors of corporate environmental information disclosure: an empirical study of Chinese listed companies, Journal of Cleaner Production, Vol17, pp. 593-600

Leuz, C. (1999). Proprietary versus non-proprietary disclosures: voluntary cash flow statements and business segment reports in Germany, Working Paper, Department of Business and Economics, Johann Wolfgang Goethe-Universita"t, Frankfurt.

Malone, D., Fries, C., Jones, T., (1993). An empirical investigation of the extent of corporate financial disclosure in the oil and gas industry, Journal of Accounting, Auditing and Finance, Vol 8, pp249-273.

Mangos, N.C. and Lewis, N.R. (1995). A socio-economic paradigm for analysing managers' accounting choice behaviour, Accounting, Auditing and Accountability Journal, Vol 8 No.1, pp. 38-62.

Mitchell, R.K., Agle, B.R., Wood, D.J. (1997). Toward a theory of stakeholder identification and salience: Defining the principle of who and what really counts, Academy of Management Review, Vol22 No.4, pp. 853-886.

Mitchell, J., Chia, C. and Loh, A. (1995). Voluntary disclosure of segment information: further Australian evidence, Accounting and Finance, Vol. 35 No.2, pp. 1-16.

Mohd Ghazali N.A and Weetman. P. (2006). Perpetuating traditional influences: Voluntary disclosure in Malaysia following the economic crisis, Journal of International Accounting, Auditing and Taxation, Vol. 15 pp. 226-248.

Nazli Ahmad, N. Maliah, S. and Siswantoro, D. (2003). Corporate Social Responsibility in Malaysia:An Analysis of Annual Reports of KLSE listed Companies, IIUM Journal of Economics and Management, Vol.11, No.1

Ng, L. W. (1985). Social responsibility disclosures of selected New Zealand companies for 1981, 1982 and 1983, Occasional Paper No. 54, Massey University, Palmerston North, New Zealand

O'Donovan, G. (2002). Environmental Disclosures in the Annual Report, Accounting, Auditing \& Accountability Journal, Vol. 15 No. 3, pp. 344-371. 
Patten, D.M. (1991). Exposure, legitimacy, and social disclosure, Journal of Accounting and Public Policy, Vol.10, pp. 297-308.

Patten, D.M. (2002a). The relation between environmental performance and environmental disclosure: a research note, Accounting, Organizations \& Society, Vol 27 No.8, pp. 763-764.

Patten, D.M. (2002b). Give or take on the internet: an examination of the disclosure practices of insurance firm web innovators, Journal of Business Ethics, Vol. 36 No. 3, pp. 247-259.

Prencipe, A. (2004). Proprietary Costs and Determinants of Voluntary Segment Disclosure: Evidence from Italian Listed Companies, European Accounting Review, Vol.13 No.2, 319-340.

Purushothaman, M., Tower, G., Hancock, R. and Taplin, R. (2000). Determinants of corporate social reporting practices of listed Singapore companies, Pacific Accounting Review, Vol. 12 No. 2, pp. 101-133.

PricewaterhouseCoopers, (2002). 2002 Sustainability survey report, PricewaterhouseCoopers.

Raman,S.R. (2006). Corporate social reporting in India-A view from the top, Global Business Review, Vol.7,pp. 313-24.

Riaz, S. (2009). The Global Financial Crisis: An Institutional Theory Analysis, Critical perspectives on international business, Vol 5 No. 1/2, pp. 26-35.

Richardson J. A., and Welker, M. (2001). Social disclosure, financial disclosure and the cost of equity capital, Accounting, Organizations and Society, Vol. 26 pp. 597-616

Rowe A. L., (2010). Corporate Kangaroos' and Dragons' Sustainability Disclosures: A Comparative Analysis. Paper presented at The $6^{\text {th }}$ Asia Pacific Interdisciplinary Research in Accounting Conference.

Salamon, G. and Dhaliwal, D. (1980). Company size and financial disclosure requirements with evidence from the segmental reporting issue, Journal of Business Finance and Accounting, Vol.7 No. 4, pp.555-568.

Singh, D.R. and J.M. Ahuja. (1983). Corporate Social Reporting in India, International Journal of Accounting, Vol. 18, No. 2, pp. 151-170.

Smith, J.V., Adhikari, A. and Tondkar, R.H. (2005). Exploring Differences in Social Disclosures Internationally: A Stakeholder Perspective, Journal of Accounting and Public Policy, Vol-24, pp123-151.

Souto, B.F. (2009). Crisis and Corporate Social Responsibility: Threat or Opportunity?, International Journal of Economic Sciences and Applied Research, Vol. 2 No.1, pp. 36-50.

SustainAbility/UNEP. (2002). Trust Us. The Global Reporters 2002 Survey of Corporate Sustainability Reporting. London: Sustainability and UNEP.

Tilt, C.A. (2001). The Content and Disclosure of Australian Corporate Environmental Policies, Accounting, Auditing and Accountability Journal, Vol 14, No 2, pp. 190-212.

Tilt, C. A. (1994). The influence of external pressure groups on corporate social disclosure: Some empirical evidence', Accounting, Auditing \& Accountability Journal, Vol. 7 No. 4, pp. 47-72.

Tinker, T. and Niemark, M. (1987). The role of annual reports in gender and class contradictions at General Motors, Accounting, Organizations and Society, Vol 12 No.1, pp. 65-88.

Verrecchia, R. (1983). Discretionary disclosure, Journal of Accounting and Economics, Vol 5, pp. 179-194.

Wagenhofer, A. (1990). Voluntary disclosure with a strategic opponent, Journal of Accounting and Economics, Vol. 12, pp. 341-363.

Wallace, R.S.O., Naser, K., Mora, A. (1994). The relationship between the comprehensiveness of companies annual reports and firms characteristics in Spain, Accounting and Business Research, Vol. 25,pp41-53.

Woodward, D.G. (1998). Specification of a content-based approach for use in corporate social reporting analysis, Southampton Institute working paper.

Zeghal, D. and Ahmed, S. A. (1990). Comparison of social responsibility information disclosure media used by Canadian firms, Accounting, Auditing \& Accountability Journal, Vol.3 No1pp38-53.

Notes

Note 1. Lehman Brothers Holdings Inc Annual Report for year ended November 30, 2007 
Table 1. Descriptive Statistics for Independent Variables of 48 Sample Companies (Year 2006 and Year 2008-2006)

\begin{tabular}{|c|c|c|c|c|c|}
\hline Variables & Mean & Median & SD & Minimum & Maximum \\
\hline ROE 06 & -0.250 & 0.020 & 1.028 & -5.870 & 0.433 \\
\hline ROE 08-06 & -0.662 & -0.225 & 2.406 & -11.950 & 6.677 \\
\hline LEV 06 & 0.491 & 0.127 & 0.880 & -0.584 & 5.017 \\
\hline LEV 08-06 & 0.410 & 0.108 & 2.095 & -6.436 & 12.307 \\
\hline SIZE 06 & 6.953 & 7.155 & 1.347 & 3.524 & 9.144 \\
\hline
\end{tabular}

Table 2. Descriptive Statistics for Dependent Variables of 48 Sample Companies (Year 2006 and Year 2008-2006)

\begin{tabular}{|c|c|c|c|c|c|c|}
\hline & $\mathbf{N}$ & Mean & Median & SD & Min & Max \\
\hline CSD 06 & 48 & 3.021 & 2.500 & 2.037 & 0 & 9 \\
\hline$\Delta$ CSD & 48 & 0.063 & 0.000 & 1.590 & -3 & 3 \\
\hline
\end{tabular}

Table 3. Number of Items Disclosed Under Each Category by All the Selected Companies and Paired T-test Results

\begin{tabular}{|c|c|c|c|c|c|c|c|c|c|c|c|c|c|c|}
\hline & $\begin{array}{c}\text { No. } \\
\text { of } \\
\text { CSD } \\
\text { in } \\
\text { Year }\end{array}$ & $\begin{array}{l}\% \text { of } \\
\text { Total } \\
\text { CSD }\end{array}$ & $\begin{array}{c}\text { No. } \\
\text { Of } \\
\text { CSD } \\
\text { in } \\
\text { Year }\end{array}$ & $\begin{array}{l}\% \text { of } \\
\text { Total } \\
\text { CSD }\end{array}$ & $\begin{array}{l}\text { No. Of } \\
\text { CSD } \\
\text { change }\end{array}$ & $\begin{array}{c}\% \text { of } \\
\text { CSD } \\
\text { change } \\
\text { from } \\
\text { Year }\end{array}$ & Mean & Mean & $\begin{array}{c}\text { Change } \\
\text { of } \\
\text { Mean }\end{array}$ & SD & SD & $\begin{array}{l}\text { Change } \\
\text { of SD }\end{array}$ & $\begin{array}{l}\text { T-Val } \\
\text { ue }\end{array}$ & $\begin{array}{c}\text { P-Valu } \\
\text { e }\end{array}$ \\
\hline & 2006 & 2006 & 2008 & 2008 & 08-06 & 08-06 & 06 & 08 & 08-06 & 06 & 08 & 08-06 & & \\
\hline CSD & 145 & $9.15 \%$ & 148 & $9.34 \%$ & 3 & 0.19 & 3.021 & 3.083 & 0.063 & 2.037 & 2.431 & 1.590 & 0.27 & 0.787 \\
\hline \multicolumn{15}{|c|}{ Dimension of Social Disclosure } \\
\hline Community & 6 & $4.05 \%$ & 6 & $4.04 \%$ & 0 & $-0.00 \%$ & 0.125 & 0.125 & 0.000 & 0.393 & 0.393 & 0.000 & 0.00 & 1.000 \\
\hline Environmental & 64 & $44.14 \%$ & 73 & $49.32 \%$ & 9 & $14.06 \%$ & 1.333 & 1.521 & 0.188 & 1.038 & 0.922 & -0.116 & 1.42 & 0.162 \\
\hline Employee/HR & 9 & $6.21 \%$ & 16 & $10.81 \%$ & 7 & $77.78 \%$ & 0.188 & 0.333 & 0.145 & 0.491 & 0.663 & 0.172 & 2.00 & $0.051 *$ \\
\hline Customer & 14 & $9.66 \%$ & 15 & $10.14 \%$ & 1 & $7.14 \%$ & 0.292 & 0.313 & 0.021 & 0.617 & 0.657 & 0.040 & 0.27 & 0.785 \\
\hline Product & 52 & $35.86 \%$ & 38 & $25.68 \%$ & -14 & $-26.9 \%$ & 1.083 & 0.792 & -0.291 & 0.871 & 0.849 & -0.022 & -2.19 & $0.033 * *$ \\
\hline $\begin{array}{l}\text { Total No. of } \\
\text { Disclosure }\end{array}$ & 145 & $100 \%$ & 148 & $100 \%$ & & & & & & & & & & \\
\hline
\end{tabular}

* Significant at the 0.1 level, ** Significant at the 0.05 level

Table 4 \& 5. Correlation Matrix for Independent Variables Related to CSD06 \& $\Delta$ CSD

\begin{tabular}{|l|l|l|}
\hline Variables & ROE 06 & LEV 06 \\
\hline LEV 06 & -0.529 & \\
\hline & $0.000^{* * *}$ & \\
\hline SIZE 06 & 0.352 & 0.169 \\
\hline & 0.014 & 0.250 \\
\hline
\end{tabular}

\begin{tabular}{|l|l|l|}
\hline Variables & $\Delta$ ROE & $\Delta$ LEV \\
\hline$\Delta$ LEV & -0.710 & \\
\hline & $0.000^{* * *}$ & \\
\hline SIZE & 0.111 & 0.102 \\
\hline & 0.435 & 0.491 \\
\hline
\end{tabular}

\footnotetext{
* Significant at the 0.1 level, ** Significant at the 0.05 level, *** Significant at the 0.01 level (2-tailed).
} 
Table 6. Regression Results for Model 1 to Test H2a, $\mathrm{H} 3 \mathrm{a}$ and $\mathrm{H} 4 \mathrm{a}$

\begin{tabular}{|c|c|c|c|c|}
\hline \multicolumn{5}{|c|}{ CSD 06 $=-2.19+0.005$ ROE 06 - 0.072 LEV 06 + 0.755 REV 06 } \\
\hline Predictor & $\begin{array}{c}\text { Expected } \\
\text { Direction }\end{array}$ & Coef & T & P \\
\hline INTERCEPT & & -2.189 & -1.34 & 0.187 \\
\hline PROF 06 & $?$ & 0.005 & 0.01 & 0.989 \\
\hline LEV 06 & + & -0.072 & -0.18 & 0.857 \\
\hline SIZE 06 & + & 0.755 & 3.19 & $0.003 * * *$ \\
\hline S = 1.82835, R-Sq $=24.60 \%, \quad$ R-Sq (adj) $=19.40 \%, \mathrm{P}=0.006 * * *$ \\
\hline$* *$ Significant at the 5\% level, *** Significant at the $1 \%$ level. \\
\hline
\end{tabular}

Table 8. Regression Results for Model 1 Excluding Profitability (ROE)

\begin{tabular}{|c|c|c|c|c|}
\hline \multicolumn{5}{|c|}{ CSD $06=-2.201-0.076$ LEV $06+0.756$ REV 06} \\
\hline Predictor & Expt Direc & Coef & $\mathbf{T}$ & $\mathbf{P}$ \\
\hline INTERCEPT & & -2.201 & -1.58 & 0.12 \\
\hline LEV 06 & + & -0.076 & -0.25 & 0.804 \\
\hline SIZE 06 & + & 0.756 & 3.81 & $0.000^{* * *}$ \\
\hline \multicolumn{5}{|c|}{$\mathrm{S}=1.80792, \quad \mathrm{R}-\mathrm{Sq}=24.60 \%, \quad \mathrm{~F}=7.33$} \\
\hline \multicolumn{5}{|c|}{$\mathrm{R}-\mathrm{Sq}(\operatorname{adj})=21.20 \%, \quad \mathrm{P}=0.002 * * *$} \\
\hline
\end{tabular}

Table 7. Regression Results for Model 2 to Test $\mathrm{H} 2 \mathrm{~b}, \mathrm{H} 3 \mathrm{~b} \& \mathrm{H} 4 \mathrm{~b}$

\begin{tabular}{c|c|c|c|c}
\hline$\Delta \mathrm{CSD}=-0.21-0.123 \Delta \mathrm{ROE}-0.310 \Delta \mathrm{LEV}+0.046 \mathrm{REV} 06$ \\
\hline Predictor & $\begin{array}{c}\text { Expected } \\
\text { Direction }\end{array}$ & Coef & $\mathbf{T}$ & $\mathbf{P}$ \\
\hline INTERCEPT & & -0.211 & -0.18 & 0.861 \\
\hline$\Delta$ PROF & $?$ & -0.123 & -0.91 & 0.368 \\
\hline$\Delta$ LEV & + & -0.310 & -2.00 & $0.052 *$ \\
\hline SIZE 06 & + & 0.046 & 0.27 & 0.789 \\
\hline S = 1.56463, R-Sq $=9.30 \%, \quad \mathrm{R}-\mathrm{Sq}(\mathrm{adj})=3.20 \%, \quad \mathrm{P}=0.225$ \\
\hline
\end{tabular}

Table 9. Regression Results for Model 1 Excluding Change in Profitability $(\triangle \mathrm{ROE})$

\begin{tabular}{|c|c|c|c|c|}
\hline \multicolumn{4}{|c|}{$\Delta \mathrm{CSD}=-0.23-0.210 \Delta \mathrm{LEV}+0.054 \mathrm{REV}$} \\
\hline Predictor & Expt Direc & Coef & $\mathbf{T}$ & $\mathbf{P}$ \\
\hline INTERCEPT & & -0.23 & -0.19 & 0.849 \\
\hline$\Delta$ LEV 06 & + & -0.21 & -1.92 & $0.061^{*}$ \\
\hline SIZE 06 & + & 0.054 & 0.32 & 0.75 \\
\hline $\mathrm{S}=1.56164, \quad \mathrm{R}-\mathrm{Sq}=7.6 \%, \quad \mathrm{~F}=1.86$ \\
\hline $\mathrm{R}-\mathrm{Sq}($ adj $)=3.5 \%, \quad \mathrm{P}=0.168$ \\
\hline
\end{tabular}

* Significant at the 0.1 level, ${ }^{* *}$ Significant at the 0.05 level, $* * *$ Significant at the 0.01 level

Table 10. Corporate Social Disclosure Checklist

\begin{tabular}{|c|c|}
\hline I. COMMUNITY INVOLVEMENT DISCLOSURE & $\begin{array}{l}\text { III. HUMAN RESOURCE DISCLOSURE } \\
\text { 1. Consultation with employee }\end{array}$ \\
\hline 1. Community programs (health \& education) & 2. Profit sharing / bonus scheme policy \\
\hline 2. Participation in government social campaigns & 3. Discussion of employee welfare \\
\hline 3. Charitable donations / sponsorships (charity) & 4. Employment of disabled and minority groups \\
\hline 4. Political donations & $\begin{array}{l}\text { 5. Provision of training to employee } \\
\text { 6. Holiday, vacation or recreation activities for employees } \\
\text { 7. Accident information /statistics/Time lost to injuries }\end{array}$ \\
\hline II. ENVIRONMENTAL DISCLOSURE & 8. Information for Day Care, maternity leave etc \\
\hline 1. Environmental policies & 9. Information regarding employee workplace health \& safety \\
\hline $\begin{array}{l}\text { 2. Environmental protection activities/programme } \\
\text { 3. Awards/certification for environmental protection activities }\end{array}$ & 10. Employee training in organization's ethical issue and anti corruption policies \\
\hline $\begin{array}{l}\text { 4.Mention of whether the firm is subject to any environmental law } \\
\text { 5. Support for public/private action designed to protect the }\end{array}$ & IV. CUSTOMER DISCLOSURE: \\
\hline environment & 1. Who are the major customers \\
\hline $\begin{array}{l}\text { 6. Production / manufacturing process support environment } \\
\text { 7. Compliance/non-compliance with environmental laws and }\end{array}$ & 2. Improvement to customer service \\
\hline regulations. & 3. Customer awards/ratings received \\
\hline $\begin{array}{l}\text { 8. Training related to environmental awareness of people/staff } \\
\text { 9. Activities related to waste management }\end{array}$ & 4. Customer health, safety or security \\
\hline 10. Water consumption & V. PRODUCT OR SERVICE DISCLOSURE: \\
\hline 11. Energy consumption & $\begin{array}{l}\text { 1. Discussion of major types of products/activities } \\
2 \text { Improvement in product/service quality } \\
\text { 3. Quality certification for product (ISO)/product related activities } \\
\text { 4. Product Safety }\end{array}$ \\
\hline
\end{tabular}

